\title{
Correction to: Asymptotically optimal Bayesian sequential change detection and identification rules
}

\author{
Savas Dayanik ${ }^{1}$ - Warren B. Powell ${ }^{2}$ Kazutoshi Yamazaki ${ }^{3}$
}

(c) The Author(s) 2021

\section{Correction to: Ann Oper Res (2013) 208:337-370 https://doi.org/10.1007/s10479-012-1121-6}

The article Asymptotically optimal Bayesian sequential change detection and identification rules, written by Savas Dayanik, Warren B. Powell, Kazutoshi Yamazaki, was originally published electronically on the publisher's internet portal on 12 April, 2012 without open access.

With the author(s)' decision to opt for Open Choice the copyright of the article changed on 02 Sept, 2021 to (C) The Author(s).

Open Access This article is licensed under a Creative Commons Attribution 4.0 International License, which permits use, sharing, adaptation, distribution and reproduction in any medium or format, as long as you give appropriate credit to the original author(s) and the source, provide a link to the Creative Commons licence, and indicate if changes were made.

The images or other third party material in this article are included in the article's Creative Commons licence, unless indicated otherwise in a credit line to the material. If material is not included in the article's Creative Commons licence and your intended use is not permitted by statutory regulation or exceeds the permitted use, you will need to obtain permission directly from the copyright holder.

To view a copy of this licence, visit http://creativecommons.org/licenses/by/4.0/.

The original article can be found online at https://doi.org/10.1007/s10479-012-1121-6.

Kazutoshi Yamazaki

k-yamazaki@sigmath.es.osaka-u.ac.jp

Savas Dayanik

sdayanik@bilkent.edu.tr

Warren B. Powell

powell@princeton.edu

1 Departments of Industrial Engineering and Mathematics, Bilkent University, Bilkent, 06800 Ankara, Turkey

2 Department of Operations Research and Financial Engineering, Princeton University, Princeton, NJ 08544, USA

3 Center for the Study of Finance and Insurance, Osaka University, 1-3 Machikaneyama, Toyonaka, Osaka 560-8531, Japan 
Open Access This article is licensed under a Creative Commons Attribution 4.0 International License, which permits use, sharing, adaptation, distribution and reproduction in any medium or format, as long as you give appropriate credit to the original author(s) and the source, provide a link to the Creative Commons licence, and indicate if changes were made. The images or other third party material in this article are included in the article's Creative Commons licence, unless indicated otherwise in a credit line to the material. If material is not included in the article's Creative Commons licence and your intended use is not permitted by statutory regulation or exceeds the permitted use, you will need to obtain permission directly from the copyright holder. To view a copy of this licence, visit http://creativecommons.org/licenses/by/4.0/.

Publisher's Note Springer Nature remains neutral with regard to jurisdictional claims in published maps and institutional affiliations. 